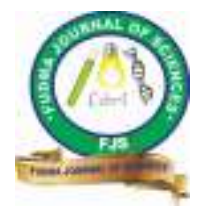

FUDMA Journal of Sciences (FJS)

ISSN online: $2616-1370$

ISSN print: 2645 - 2944

Vol. 4 No. 3, September, 2020, pp $93-98$

DOI: https://doi.org/10.33003/fjs-2020-0403-352

\title{
ASSESSMENT OF THE LEVEL OF HEAVY METAL CONCENTRATION IN THE STREET DUST IN SOME SELECTED LOCATIONS IN ZARIA METROPOLIS, KADUNA STATE, NIGERIA
}

\author{
"Nimyel, S. H., Namadi, M. M. \\ Department of Chemistry, Nigerian Defence Academy, Kaduna, Nigeria \\ *Corresponding Author's Email: nimyela@gmail.com +23408032918556
}

\begin{abstract}
The study investigate the level of heavy metal concentration in street dust in some selected locations in Zaria metropolis, by monitoring the concentration of Chromium (Cr), Cadmium (Cd), Nickel (Ni), Lead (Pb), and Copper $(\mathrm{Cu})$ for eight weeks. Street dust samples were collected by placing polyethylene bags on randomly selected roof tops and road sides at $20 \mathrm{~cm}$ to $30 \mathrm{~cm}$ to form composite sample. Sample collected were pretreated and digested using standard procedure. Atomic Absorption Spectrophotometer (AAS) was used to determine the concentration of heavy metals. Results obtained showed that the concentration of $\mathrm{Cr}$ range from $16.670 \pm 2.20 \mu \mathrm{g} / \mathrm{g}$ to $31.895 \pm 1.845 \mu \mathrm{g} / \mathrm{g}$, Cd concentration range from $0.280 \pm 0.042 \mu \mathrm{g} / \mathrm{g}$ to $1.900 \pm$ $1.202 \mu \mathrm{g} / \mathrm{g}$, Ni concentration range from $1.560 \pm 0.254 \mu \mathrm{g} / \mathrm{g}$ to $5.880 \pm 1.173 \mu \mathrm{g} / \mathrm{g}, \mathrm{Pb}$ concentration range from $22.290 \pm 2.248 \mu \mathrm{g} / \mathrm{g}$ to $95.485 \pm 3.019 \mu \mathrm{g} / \mathrm{g}, \mathrm{Cu}$ concentration range from $0.225 \pm 0.063 \mu \mathrm{g} / \mathrm{g}$ to 1.280 $\pm 0.353 \mu \mathrm{g} / \mathrm{g}$. The concentration of all heavy metals are below the limit set be World Health Organization (WHO) and therefore do not pose any health risk to humans. In sampled areas, the main sources of these heavy metals were anthropogenic activities such as open waste incineration, vehicle traffic, and ongoing construction at certain locations.
\end{abstract}

Keywords: Heavy metals, Concentration, Chromium, Cadmium, Nickel, Lead and Copper.

\section{INTRODUCTION}

Heavy metal contamination is among the major sources of air pollution. They may accumulate in the topsoil from anthropogenic activities by sedimentation, impaction, and interception. Roadside and top soil pollution in urban areas are sources of heavy metal exposure due to the atmospheric deposition. It has been reported that roadside soils near heavy traffic are polluted with $\mathrm{Pb}$ and other metals. In recent years, heavy metal pollutants in roadside dust have become a growing concern. In Nigeria, roadside dust is one of the main ways in which heavy metals can find their way into soils and, subsequently, into living tissues of plants and human beings. In the monitoring of urban pollution, consideration must be given to materials that cause the occurrence of pollutants. Chemical and biological measures are of importance as they provide information on concentrations and accumulation in the environment (Raymond and Felix, 2011).

Heavy metal contamination can occur from several causes, but most commonly results from metal purification, e.g. copper smelting and nuclear fuel preparation. Like environmental contaminants, heavy metals do not degrade and thus pose a particular kind of remediation problem. As a measure of environmental contamination, the following metals were selected for analysis: iron $(\mathrm{Fe})$, chromium $(\mathrm{Cr})$, cadmium $(\mathrm{Cd})$ and lead $(\mathrm{Pb})$ Vhahangwele and Khathutshelo (2018).

Many trace elements, in particular heavy metals, remain almost forever in the soil. Such metals remain bound to organic matter until they are mechanically remobilized as wind-blasted particles. The exposure of human to metals and their compounds in the environment is through food, drink and water. Other forms of uptake are via contact with the skin (Ewers, 1991). Over time, however, adverse toxic effects may occur as a result of long-term low-level exposure (Ewers, 1991).

Motivations for controlling the concentrations of heavy metals in gas streams are diverse, some are hazardous to health or the environment (e.g. $\mathrm{Hg}, \mathrm{Cd}, \mathrm{As}, \mathrm{Pb}, \mathrm{Cr}$ ), some may cause corrosion (e.g. $\mathrm{Zn}, \mathrm{Pb}$ ), and some are harmful in other ways (e.g. Arsenic may pollute catalysts). As, $\mathrm{Cd}, \mathrm{Co}, \mathrm{Cr}, \mathrm{Cu}, \mathrm{Hg}$, $\mathrm{Mn}, \mathrm{Ni}, \mathrm{Pb}, \mathrm{Sn}$ and $\mathrm{Tl}$, whose emissions are regulated in waste incinerators, are of the highest concern within the European Community. Some of these components are potentially essential for humans in small quantities $(\mathrm{Co}, \mathrm{Cu}, \mathrm{Cr}$, $\mathrm{Mn}, \mathrm{Ni}$ ) while others are carcinogenic or harmful, affecting, among others, the central nervous system $(\mathrm{Mn}, \mathrm{Hg}, \mathrm{Pb}, \mathrm{As})$, the kidneys or the liver $(\mathrm{Hg}, \mathrm{Pb}, \mathrm{Cd}, \mathrm{Cu})$ or the skin, bones or teeth $(\mathrm{Ni}, \mathrm{Cd}, \mathrm{Cu}, \mathrm{Cr}$ ) (Banerjee, 2003; Charlesworth et al., 2003).

\section{MATERIALS AND METHODS}

Sampling Area

Zaria lies on latitude $10^{\circ} 28^{\prime} \mathrm{N}$ and longitude $7^{\circ} 25^{\prime} \mathrm{E}$ (Africa Atlas, 2002). It is located in the central area of what used to be called the Northern Region of Nigeria. The mean annual rainfall in the area ranges from 924.3-1543.6 mm. Annual temperature varies between $29^{\circ} \mathrm{C}-38.6^{\circ} \mathrm{C}$ (Africa Atlas, 2002). Zaria is a local government in Kaduna State.

The selected areas for this investigation are areas with high traffic and business activities. These areas are busy within the hours of $6.30-8.30$ am when offices and commercial activities 
commence and $4.00-7.30 \mathrm{pm}$ in the evening at the close of work and market activities.

Four sampling locations were selected and considered for this analysis. The Sites include; Kwangila, which is characterized by a minipark for trucks, petroleum dispensing station and runoff from the gutter; Tudun Wada roundabout, which houses a mini-park for vehicles and motorcycles, with shops surrounding the site and presence of refuse dump site; Chindit barracks junction which has a $\mathrm{T}$-junction and a mini-park for motorcycles and tricycles; and Aminu road Sabon-gari which has a mini-park for motorcycles and tricycles and also has boutiques and shops with regular use of generators and other gasoline-powered equipment. The sale of building materials is also noticed around the site as well as gutter presence. A last location known as Polo field was selected to serve as control as all the activities associated with the other locations are absent here.

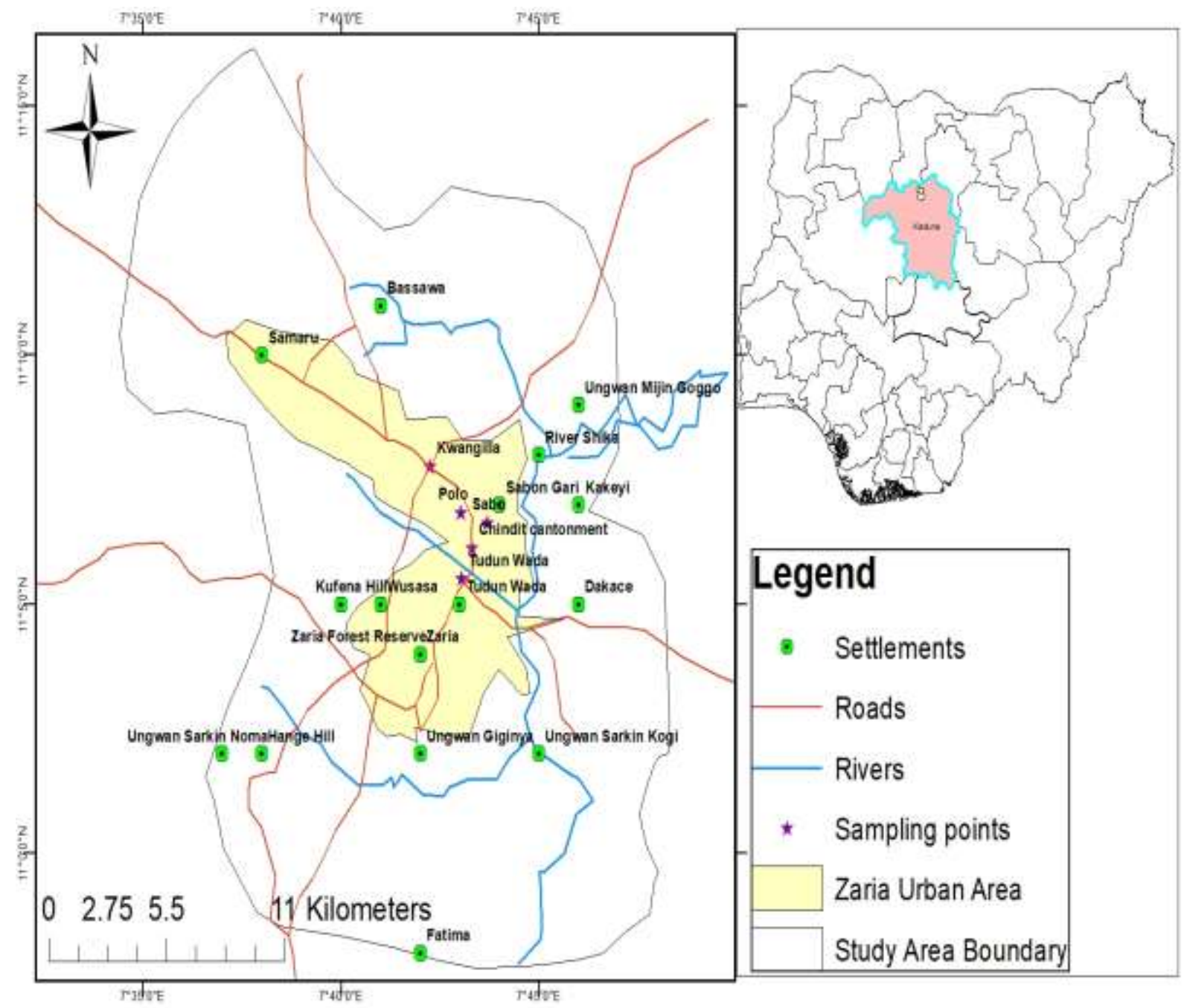

Fig. 1 Map of Zaria showing sample locations

\section{Sampling of Street Dust Particles}

Street dust samples were collected by placing polyethylene bags on randomly selected roof tops and road sides at $20 \mathrm{~cm}$ to $30 \mathrm{~cm}$ to form composite sample. The samples collected were stored in the clean polyethylene bags till the analysis. At each sampling site, composite samples were obtained by mixing subsamples from four points at each site (Marsan et al., 2008). The samples were differentiated via labeling using the respective sites in the location. The coordinate of each sample location was recorded using a Global Positioning System (GPS) Receiver (Garmin model 60 CSx).

\section{Street Dust Sample Pre-treatment}

The Samples were dried using an Oven at $105^{\circ} \mathrm{C}$ to a constant mass and then sieved through a 2-mm stainless steel sieve to remove extraneous matter. Care was taken to reduce the disturbance of the fine particles, which could be readily lost by re-suspension (Victor et al., 2013). 


\section{Digestion of Dust Sample}

The method described by Sonawane et al. (2013) was used to digest the samples. Exactly $2.0 \mathrm{~g}$ were each measured into 250 $\mathrm{cm}^{3}$ glass beakers and $8 \mathrm{~cm}^{3}$ of aqua-regia $\left(3: 1 \mathrm{HCl}\right.$ and $\left.\mathrm{HNO}_{3}\right)$ was added. The mixture was then heated at $200^{\circ} \mathrm{C}$ on a hot plate for $2 \mathrm{hrs}$. On evaporation to near dryness, the sample was then dissolved with $10 \mathrm{~cm}^{3}$ of $2 \%$ nitric acid and filtered through Whatman's No.1 filter paper before being diluted to mark with distilled. Atomic Absorption Spectrophotometer was used to determine the heavy metals in the solution.

\section{Determination of $\mathbf{p H}$}

Exactly $20 \mathrm{~g}$ of soil sample was weighed into a $100 \mathrm{~cm}^{3}$ beaker and $40 \mathrm{~cm}^{3}$ of distilled water was added. The suspension was stirred continuously at intervals for about 30 minutes to ensure adequate mixing and dissolution of all soluble compounds. Whatman No. 1 filter paper was then used to filter the mixture and the $\mathrm{pH}$ of the filtrate taken. Before use, the $\mathrm{pH}$ meter was calibrated using buffer 4 and 7 solutions and was rinsed with distilled water before and after each individual reading (Herdershot et al., 1993).

$$
\mathrm{PO}^{-3} \mathrm{mg} / \mathrm{kg}=\frac{\text { Concentration (from curve) } \times \text { Extraction Volume }}{\text { Volume of Sample aliquot } \mathrm{x} \text { Sample weight }}
$$

Determination of phosphate ( $\left.\mathrm{PO}_{4}{ }^{3-}\right)$ (Agbenin, 1995)

Precisely $15 \mathrm{~cm}^{3}$ of $1.0 \mathrm{M} \mathrm{NH}_{4} \mathrm{~F}$ and $25 \mathrm{~cm}^{3}$ of $0.5 \mathrm{M} \mathrm{KCI}$ was mixed with $460 \mathrm{~cm}^{3}$ of distilled water and the mixture stored in a glass bottle giving the extraction solution. Exactly $0.2197 \mathrm{~g}$ of $\mathrm{KH}_{2} \mathrm{PO}_{4}$ was oven dried at $105^{\circ} \mathrm{C}$ for 1 hour, dissolved in distilled water and diluted to $1000 \mathrm{~cm}^{3}$ in a volumetric flask giving phosphate stock solution $\left(1 \mathrm{~cm}^{3}=0.05 \mathrm{mg}\right)$. Working standards of $5,10,15,20$ and $25 \mu \mathrm{g} \mathrm{PO} 4^{-3}$, were prepared. Absorbances were read with colorimeter at $690 \mathrm{~nm}$ and a calibration curve of absorbance versus concentration was plotted. Precisely $5 \mathrm{~g}$ of the dust sample was weighed into an extraction bottle and $35 \mathrm{~cm}^{3}$ of extraction solution was added. The bottle was shaken for 1 minute and filtered into dry beaker. Filtration was repeated until filtrate was clear. $10 \mathrm{~cm}^{3}$ of the filtrate was shaken with $0.4 \mathrm{~cm}^{3}$ of ammonium molybadate reagent (Denige's reagent) and 2 drops of stannous chloride were added. Absorbance was measured after 11 minutes for all samples at $690 \mathrm{~nm}$ and concentration read from the curve. Victor et al.,

$(2013)$
Determination of Chloride Victor et al., (2013)

Exactly $20 \mathrm{~g}$ of the dust sample was dried at $110^{\circ} \mathrm{C}$ for $1 \mathrm{hr}$ and cooled in a desiccator. $10 \mathrm{~g}$ of the sample was weighed into a $250 \mathrm{~cm}^{3}$ Erlenmeyer flask and dissolved to about $40 \mathrm{~cm}^{3}$ of distilled water stirred with a glass rod and allow to stand overnight. $20 \mathrm{~cm}^{3}$ of the extract was pipetted into a $25 \mathrm{~cm}^{3}$ conical flask. About 4 drops of $\mathrm{K}_{2} \mathrm{CrO}_{4}$ was introduced and the solution was titrated with $0.01 \mathrm{~mol} / \mathrm{dm}^{3} \mathrm{AgNO}_{3}$ to the first permanent appearance of red $\mathrm{Ag}_{2} \mathrm{Cr}_{2} \mathrm{O}_{4}$.

$\mathrm{Cl}^{-} \mathrm{mg} / \mathrm{kg}=$ Titre $\left(\mathrm{cm}^{3}\right) \times$ Molality $\left(\mathrm{AgNO}_{3}\right)$ x Extraction Volume $\mathrm{x} 103$ Weight of Sample $x$ Volume of Sample Aliquot $\left(\mathrm{cm}^{3}\right)$

RESULTS AND DISCUSSION

Heavy Metal Pollution of the Dust Particle

\begin{tabular}{|c|c|c|c|c|c|c|}
\hline $\mathrm{S} / \mathrm{N}$ & & $\mathrm{Cr}$ & $\mathrm{Cd}$ & $\mathrm{Ni}$ & $\mathrm{Pb}$ & $\mathrm{Cu}$ \\
\hline 1 & T/Wada & $17.190 \pm 0.381 \mathrm{a}$ & $0.385 \pm 0.021 \mathrm{a}$ & $2.705 \pm 0.219 \mathrm{ab}$ & $28.180 \pm 1.173 a$ & $0.430 \pm 0.084 a$ \\
\hline 2 & S/Gari & $17.345 \pm 2.227 \mathrm{a}$ & $1.900 \pm 1.202 b$ & $3.745 \pm 0.346 b$ & $95.485 \pm 3.019 \mathrm{~d}$ & $1.280 \pm 0.353 b$ \\
\hline 3 & Polo field & $16.670 \pm 2.220 \mathrm{a}$ & $0.280 \pm 0.042 \mathrm{a}$ & $1.560 \pm 0.254 \mathrm{a}$ & $22.290 \pm 2.248$ & $0.225 \pm 0.063 a$ \\
\hline 4 & Kwangila & $20.675 \pm 0.742 \mathrm{a}$ & $0.550 \pm 0.042 \mathrm{ab}$ & $5.880 \pm 1.173 \mathrm{c}$ & $41.76 \pm 2.001 b$ & $0.255 \pm 0.063 \mathrm{a}$ \\
\hline 5 & $\begin{array}{l}\text { Chindit } \\
\text { Junction }\end{array}$ & $31.895 \pm 1.845 b$ & $0.455 \pm 0.346 \mathrm{ab}$ & $2.750 \pm 0.339 \mathrm{ab}$ & $60.255 \pm 4.023 \mathrm{c}$ & $0.605 \pm 0.091 \mathrm{a}$ \\
\hline & ANOVA & 0.001 & 0.140 & 0.005 & 0.001 & 0.008 \\
\hline
\end{tabular}

Table 1: Concentration of some Heavy Metals in Dust Sample from different Sampling Points in $\mu \mathrm{g} / \mathrm{g}$.

Values are mean \pm standard deviation of replicate measurements

Table 1 shows the levels of these heavy metals across the five site Tudun wada, Sabon gari, Polo field, Kwangila junction and Chindit Junction respectively, their respective values are as follow: $\mathbf{C r} 17.190 \pm 0.381 \mathrm{a}, 17.345 \pm 2.227 \mathrm{a}, 16.670 \pm 2.220 \mathrm{a}$, $20.675 \pm 0.742 \mathrm{a}$ and $31.895 \pm 1.845 \mathrm{~b}, \mathbf{C d} 0.385 \pm 0.021 \mathrm{a}, 1.900 \pm 1.202 \mathrm{~b}, 0.280 \pm 0.042 \mathrm{a}, 0.550 \pm 0.042 \mathrm{ab}$ and $0.455 \pm 0.346 \mathrm{ab}$, Ni $2.705 \pm 0.219 \mathrm{ab}, 3.745 \pm 0.346 \mathrm{~b}, 1.560 \pm 0.254 \mathrm{a}, 5.880 \pm 1.173 \mathrm{c}$ and $2.750 \pm 0.339 \mathrm{ab}, \mathbf{P b} 28.180 \pm 1.173 \mathrm{a}, 95.485 \pm 3.019 \mathrm{~d}$,

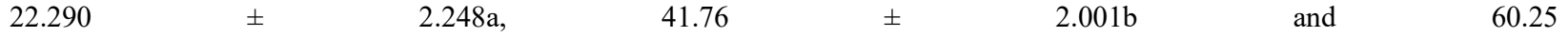
$\pm 4.023 \mathrm{c}, \mathbf{C u} 0.430 \pm 0.084 \mathrm{a}, 1.280 \pm 0.353 \mathrm{~b}, 0.225 \pm 0.063 \mathrm{a}, 0.255 \pm 0.063 \mathrm{a}$ and $0.605 \pm 0.091 \mathrm{a}$. 
Copper was found to be the least metal in all the sites while lead was the highest metal found in all locations. This could be so because lead is the main product of gasoline combustion.

The results as shown in Table 1, shows that the highest level of chromium $(\mathrm{Cr})$ in street dust samples were found in at Chindit Junction (mean $=31.895 \mu \mathrm{g} / \mathrm{g}$ ); while the lowest is found in Polo Field $($ mean $=16.670 \mu \mathrm{g} / \mathrm{g}$ ). The level of chromium in the investigated area was generally lower than the set standards by world health Organization (WHO). The level of chromium in all the sites were generally lower than those determined in other cities in developed countries (El-Sayed et al., 2010 and Victor 2011). Similarly, Akilu (2013) as obtained maximum $\mathrm{Cr}$ concentration was $126.17 \mu \mathrm{g} / \mathrm{g}$ and minimum value was 92.86 $\mu \mathrm{g} / \mathrm{g}$ at depth of $0-10 \mathrm{~cm}$ in tannery effluents in Ethiopia which was also lower than the results obtained. Although chromium is a major part of automobile bodies, it's concentration in the samples are not considered dangerous (El-Hassan et al., 2006). Concentration of $\mathrm{Cr}$ in this study did not exceed the limit set by the United Kingdom of $300 \mu \mathrm{g} / \mathrm{g}$ and $100 \mathrm{mg} / \mathrm{L}$ by WHO (Solano, 2013).

The highest mean for cadmium $(\mathrm{Cd})$ concentration was found in Sabon Gari $(1.900 \mu \mathrm{g} / \mathrm{g})$ with the minimum at Polo Field $(0.280 \mu \mathrm{g} / \mathrm{g})$. The levels of cadmium in the samples were generally lower than the permissible limit of $(0.5-4.0 \mu \mathrm{g} / \mathrm{g}$; Fergusson and Kim, 1991). The dust sample in this study showed higher levels of cadmium contamination than $0.75 \mu \mathrm{g} / \mathrm{g}$ (Jaradat et al., 1999), 2.11 $\mathrm{g} / \mathrm{g}$ (Amusan et al., 2003) and 1.47 $\mu \mathrm{g} / \mathrm{g}$ (Victor, 2011). The levels of cadmium could be due to lubricating oils and/or old tires that are frequently used on the roads which increase the wearing of tires.

The values of $\mathrm{Ni}$ in the dust samples were found to be within the range $1.560-5.880 \mu \mathrm{g} / \mathrm{g}$. The highest mean value of nickel was found in the sample from Kwangila while the lowest in
Polo Field. The mean concentration of nickel was lower than the world-wide value $(50-100 \mu \mathrm{g} / \mathrm{g})$ (Fergussion and Kim, 1991) and with the range of 0.3 to $0.6 \mu \mathrm{g} / \mathrm{g}$ as found by Victor O., (2011), thus, it does not pose any health risk. Nickel pollution on a local scale is caused by emission from vehicle engines that use nickel gasoline and by the abrasion and corrosion of nickel from vehicle parts (Al-Shayep and Seaward, 2001).

The highest lead $(\mathrm{Pb})$ values were detected in street dust samples collected from Sabon Gari $(95.485 \mu \mathrm{g} / \mathrm{g})$. The minimum was found in Polo Field $(22.290 \mu \mathrm{g} / \mathrm{g})$. It is as well within the permissible limit and does not pose any major health problem. This is in agreement with the report of Abechi et al., (2010) and Victor O. (2011). When compared with other literatures the mean concentration of lead was found to be lower than those reported by $236 \mu \mathrm{g} / \mathrm{g}$ for Amman, Jordan, $697.2 \mu \mathrm{g} / \mathrm{g}$ for Bahrain, $265 \mu \mathrm{g} / \mathrm{g}$ for Manchester, UK, Australia $(100 \mu \mathrm{g} / \mathrm{g})$, Poland $(100 \mu \mathrm{g} / \mathrm{g})$, and United Kingdom $(100 \mu \mathrm{g} / \mathrm{g})$ and Germany $(500 \mu \mathrm{g} / \mathrm{g})$ (Mamtaz \& Chowdhury, 2006).

The level of $\mathrm{Cu}$ in the street dust collected from the sampled site varied from $0.225-1.280 \mu \mathrm{g} / \mathrm{g}$. The highest $\mathrm{Cu}$ level was found at Sabon Gari and the lowest was at Polo Field the control site. According to the research made by Odoh et al. (2011) and Najib et al. (2012), the result of copper obtained were $238.33 \mu \mathrm{g} / \mathrm{g}$ and $623.7 \mu \mathrm{g} / \mathrm{g}$ respectively which was found to be higher. Improper disposal of waste lubricant and other anthropogenic activities are responsible for copper found in street dust. Results obtained are however below the permissible limits set by Great Britain $(100 \mathrm{mg} / \mathrm{Kg})$, Canada $(100 \mathrm{mg} / \mathrm{Kg})$, Japan $(125 \mathrm{mg} / \mathrm{Kg})$ and Poland $(100 \mathrm{mg} / \mathrm{Kg})$ (Pam et al., 2013)

Correlation between Heavy Metal Concentrations in Street Dust

Table 2: Correlation Matrix among Heavy Metals in $\mu \mathrm{g} / \mathrm{g}$.

\begin{tabular}{|c|c|c|c|c|c|}
\hline & $\mathrm{Cr}$ & $\mathrm{Cd}$ & $\mathrm{Ni}$ & $\mathrm{Pb}$ & $\mathrm{Cu}$ \\
\hline $\mathrm{Cr}$ & 1 & & & & \\
\hline $\mathrm{Cd}$ & -.230 & 1 & & & \\
\hline $\mathrm{Ni}$ & .033 & .275 & 1 & & \\
\hline $\mathrm{Pb}$ & .199 & $.908^{* *}$ & .285 & 1 & \\
\hline $\mathrm{Cu}$ & -.009 & $.935^{* *}$ & .060 & $.940^{* *}$ & 1 \\
\hline
\end{tabular}

The correlation between Heavy metals in street dust gotten from the various sampling sites was calculated using the SPSS (Statistical program for the social sciences) computer software package (SPSS Inc., version 17). The strength of the linear relationship between any two variables on a scale of -1 (perfect inverse relation) through 0 (no relation) to +1 (perfect sympathetic relation) is measured by the coefficient.
From Table 2, the correlation coefficient statistical analysis conducted on the metal concentrations at $95 \%$ and $99 \%$ confidence level indicates a significant positive correlation relationship between $\mathrm{Ni}$ and $\mathrm{Cd}(\mathrm{r}=0.330 \mu \mathrm{g} / \mathrm{g})$ and between $\mathrm{Ni}$ and $\mathrm{Cd}(\mathrm{r}=0.275 \mu \mathrm{g} / \mathrm{g}), \mathrm{Pb}$ and $\mathrm{Cr}(\mathrm{r}=0.199 \mu \mathrm{g} / \mathrm{g}), \mathrm{Pb}$ and $\mathrm{Cd}(\mathrm{r}=0.908 \mu \mathrm{g} / \mathrm{g}), \mathrm{Pb}$ and $\mathrm{Ni}(\mathrm{r}=0.285 \mu \mathrm{g} / \mathrm{g}), \mathrm{Cu}$ and $\mathrm{Cd}(\mathrm{r}=$ $0.935 \mu \mathrm{g} / \mathrm{g}), \mathrm{Cu}$ and $\mathrm{Ni}(\mathrm{r}=0.060 \mu \mathrm{g} / \mathrm{g})$ and $\mathrm{Cu}$ and $\mathrm{Pb}(\mathrm{r}=$ 
$0.940 \mu \mathrm{g} / \mathrm{g}$ ). This relationship shows the interdependence of these metal pairs and could be said to be due to the presence of these metals in similar source (i.e. the body parts and tires of automobiles as well as vehicular emissions). Negative correlation relationship was found between $\mathrm{Cd}$ and $\mathrm{Cr}(\mathrm{r}=-$
$0.230 \mu \mathrm{g} / \mathrm{g})$, and $\mathrm{Cu}$ and $\mathrm{Cd}(\mathrm{r}=-0.009 \mu \mathrm{g} / \mathrm{g})$, this shows that sources other than automobile emission, wear and tire of body parts and tires could contribute to concentration of these metals in the street dust.

\section{Physiochemical Parameters of Street Dust in the Sampling Sites}

Table 3: Mean pH, Concentration of chloride and phosphate at sampling point

\begin{tabular}{lllll}
\hline $\mathrm{S} / \mathrm{N}$ & & $\mathrm{P}^{\mathrm{H}}$ & Chloride $(\mathrm{mg} / \mathrm{kg})$ & Phosphate $(\mathrm{mg} / \mathrm{kg})$ \\
\hline 1 & T/Wada & $6.930 \pm 0.098 \mathrm{ab}$ & $13.440 \pm 1.046 \mathrm{a}$ & $0.880 \pm 0.141 \mathrm{ab}$ \\
& & & & \\
2 & S/Gari & $8.520 \pm 0.452 \mathrm{c}$ & $108.835 \pm 3.514 \mathrm{c}$ & $1.12500 \pm 0.247 \mathrm{~b}$ \\
& & & $72.715 \pm 2.566 \mathrm{~b}$ & $0.540 \pm 0.183 \mathrm{a}$ \\
3 & Polo field & $6.675 \pm 0.502 \mathrm{ab}$ & $135.590 \pm 8.782 \mathrm{~d}$ & $0.430 \pm 0.098 \mathrm{a}$ \\
4 & Kwangila & $6.470 \pm 0.339 \mathrm{a}$ & $205.500 \pm 10.182 \mathrm{e}$ & $1.165 \pm 0.176 \mathrm{~b}$ \\
5 & $\begin{array}{l}\text { Chindit } \\
\text { Junction }\end{array}$ & $7.420 \pm 0.113 \mathrm{~b}$ & & \\
& & & 0.001 & 0.027 \\
\hline
\end{tabular}

Table 3, shows the mean $\mathrm{pH}$, concentration of Chloride and Phosphate at different sampling points within Zaria Metropolis which in the order of $\mathrm{pH}$ is Sabon gari $>$ Chindit Junction $>$ Tudun wada $>$ Polo field $>$ Kwangila junction, for chloride is Chindit Junction $>$ Kwangila junction $>$ Sabon gari $>$ Polo field $>$ Tudun wada and for phosphate is Chindit Junction $>$ Sabon gari $>$ Tudun wada $>$ Polo field $>$ Kwangila Junction.

The physiochemical parameters of street dust within the study area is as shown in Table 4.2. The $\mathrm{pH}$ level ranges from 6.47-8.52 which indicates slightly acidic to slightly alkaline conditions. This is within the range as reported by Tanushree et al., (2013). The $\mathrm{pH}$ serves as useful index for availability of nutrients, the potency of toxic substances presents in the soil and the physical properties of the soil. Several studies have shown that availability of heavy metals is $\mathrm{pH}$ dependent (Iwegbue et al., 2006). The $\mathrm{pH}$ values of the study areas indicated tendency for availability of these heavy metals.

The level of phosphate and Chloride varied from $0.0430 \mathrm{mg} / \mathrm{L}-1.165 \mathrm{mg} / \mathrm{L}$ and $13.440 \mathrm{mg} / \mathrm{L}-205.500 \mathrm{mg} / \mathrm{L}$ respectively.

\section{CONCLUSION}

The study ssessed the level of heavy metals $(\mathrm{Cr}, \mathrm{Cd}, \mathrm{Cu}$. Ni and $\mathrm{Pb})$ concentrations in high traffic areas in some selected locations in Zaria Local Government Area, Kaduna State. The results indicated that the mean concentration of the heavy metals in street dust samples were in the order $\mathrm{Pb}>\mathrm{Cr}>\mathrm{Ni}>$ $\mathrm{Cd}>\mathrm{Cu}$. The continual usage of gasoline powered vehicles, motorcycles, tricycles, and other equipments on the road could lead to the accumulation of these metals, therefore continuous inhalation by humans could be detrimental to health.

\section{ACKNOWLEDGMENT}

The author acknowledge the financial support of the Nigerian Army and tertiary education trust fund (TETFUND) and Nigerian Defence academy for providing the platform for this research.

\section{REFERENCE}

Abechi, E.S.; Okunola, O.J.; Zubairu, S.M.J; Usman, A.A. and Apene, E. (2010). Evaluation of Heavy Metals in Roadside Soils of Major Street in Jos Metropolis, Nigeria. Journal of Environmental Chemistry and Ecotoxicoloty Vol. 2(6), 98-102. Agbenin, J.O. (1995). Laboratory Manual for Soil and Plant
Analysis, Department of Soil Science. Ahmadu Bello University, Zaria. Pp. 15-52.

Akilu, A. (2013). Heavy Metals Concentration in Tannery Effluents, Associated Surface Water and soil at Ejersa Area of East Shoa, Ethiopia. Merit Research Journals of Environmental Science and Toxicology, 1(8), 156-163.

Al-Shayep, S.M., and Seaward, and M.R.D (2001). Heavy Metal Content of Roadside Soils along Ring Road in Riyadh (Saudi Arabia). Asian Journal of Chemistry. 13:407-423.

Amusan A.A., Bada S.B., and Salami A.T (2003). Effects of Traffic Density on Heavy Metal Content of Soil and Vegetation along Roadside in Osun State, Nigeria. West Africa. J. App. Ecol., 4:107-114.

Banerjee, A. D. K. (2003). "Heavy Metal Levels and Solid Phase Speciation in Street Dust of Delhi, India", Journal of Environmental Pollution, vol. 123, pp95-105.

Charles worth, S., et al., (2003). "A Comparative Study of Heavy Metal Concentration and Distribution in Deposited 
Street Dusts in a Large and a Small Urban Area: Birmingham and Coventry, West Midlands, UK", Environment International, Vol.29, No.5, pp563-573.

El-Hassan, T., Mufeed B., Al-Omari, H., Ziadat, A., El-Alali, A., Al-Naser, F., Berdanier, B.W and Jiries, A. (2006). The Distribution of Heavy Metals in Urban Street Dusts of Karak City, Jordan. Soil and Sediment Contamination, 15, 357-365.

Ewers, U. (1991). "Standards, Guidelines and Legislative Regulations Concerning Metals and their Compounds in Merian E. (Ed) Metals and their Compounds in the Environment VCH", Verlags Gesell's chaftmb H, Wembheim, New York, pp687-750.

Fergusson, J.E. and Kim, N.D. (1991). Trace Metal Elements in Street and House. Dusts: Sources and Speciation. The Science of the Total Environment, 100:125- 150.

Hendershot, W.H., Lalande, H. and Duguete, M. (1993). Soil Reaction and Exchangeable Acidity. In: Carter, M.R (ed). Soil Sampling and Methods of Analysis for Canadian Society of Soil Science, Boca Raton, FL. 141 - 145.

Iwegbue, C.M.A., Isirimah, N.O., Igwe, C. and Williams, E.S. (2006). Characteristic Levels of Heavy Metal in Soil Profile of Automobile Mechanic Waste Dumps in Nigeria. Environmentalist, 26:123-128.

Jaradat, Q., Momani, K., Jiriss, A., El-Alali, A., Batarseh, M., Sabri, T.G., and Al-Momani, I. (1999). Chemical Composition of Urban Wet Deposition in Amman, Jordan. Water, Air and Soil Pollution 112, 55-65.

Mamtaz, R. and Chowdhury, H. (2006). Leaching characteristics of solid waste at an urban solid waste dumping site. Journal of Civil Engineering, 34, 71-79.

Marsan, F.A., Biasioli, M., Kralj, T., Greman, H., Davidson, C.M., Husthouse, A.S., Madrid, L. and Rodrigues, S. (2008). Metals in Particle Size Fraction of the Soil of Five European Cities, Environmental Pollution, 152:73-81.

Najib, N.W.A.Z., Mohammed, s.a., Ismail, S.A., and Ahmad, W.A.A.W. (2012). Assessment of Heavy Metal in soil due to Human Activities in Kangar, Perlis, Malaysia.

Odoh, R., Agboji, E. B., and Kagbu, J. A. (2011). Assessment of Trace Metals Pollution in Auto-Mechanic Workshop in Some Selected Local Government Areas of Benue State, Nigeria. International Journal of Chemistry, 3(4), 78-88.
Pam, A. A., Sha'Ato, R., and Offem, J. O. (2013). Contributions of Automobile Mechanic Sites to Heavy Metals in Soil: A Case Study of North Bank Mechanic Village Makurdi, Benue State, Central Nigeria. Journal of Chemical, Biological, and Physical Sciences, 3(3), 2337-2347.

Rarmond, A. W and Felix, E. O. (2011). Heavy Metals in Contaminated Soils: A Review of Sources, Chemistry, Risks and Best Available Strategies for Remediation. International Schorlarship Research Notices. Vol 2011.

Salano, E. M. (2013). Assessment of Heavy Metal Pollution in Soils and water of Samburu County, Kenya. Masters' Thesis, Kenyatta University, Kenya. Retrieved on $2^{\text {nd }}$ May 2019 from www.google.com/heavymetalsinwater/solanoerick

Sonawane, N. S., Sawant, C. P. and Patil, R. V. (2013). Soil Quality and Heavy Metal Contamination in Agricultural Soil in and around Toronmal (Triable Region) Of Maharashtra. Archives of Applied Science Research, 5(2), 294-298

Tanushree Bhattcharya, Sukalyan Chakraborty, Dhara Tuteja, and Mitul Patel. (2013). Zinc and Chromium in road dust suspended particulate matter and foliar dust deposits of Anand city, Gujarat. Open journals of metals 5(2), pp 78-84.

Victor, O., Ajibola, V. O., Ekwumengbo, P. A., Yilleng, M. T., Odey, M. O., Ahmed, A. I., and Hassanien, M. M. (2013). Some Physicochemical Parameters and Heavy Metal Presence in Street Dust of Sabon-Gari Market, Zaria, Nigeria. International Journal of Modern Chemistry, 5(2), 7186.

Victor, O (2011). Pollutants in Air and Heavy Metals in Street Dust of Some Selected Locations in Zaria. M.Sc. Thesis Submitted to Department of Chemistry, Ahmadu Bello University, Zaria.

Vhahangwele M. and Khathutshelo L. M. (2018). Environmental Contamination by Heavy Metals. DOI: 10.5772/intechopen.76082. 